\title{
CLADONIA DIVERSA (CLADONIACEAE, LICHENIZED ASCOMYCOTA) - OVERLOOKED LICHEN IN POLAND
}

\author{
PIOTR OSYCZKA \\ Department of Polar Research and Documentation, \\ Institute of Botany, Jagiellonian University \\ Kopernika 27, 31-501 Kraków, Poland \\ e-mail: piotr.osyczka@uj.edu.pl
}

(Received: December 2, 2008. Accepted: May 26, 2009)

\begin{abstract}
This is the first report on Cladonia diversa Asperges in Poland. Till the present this species was overlooked and usually included under the name $C$. coccifera. The study is based on revision of over a thousand of specimens of the genus Cladonia section Cocciferae deposited in Polish herbaria. The morphology, chemistry, habitat requirements and known distribution of the lichen in Poland are discussed. A taxonomical remarks concerning the species are also provided.
\end{abstract}

KEY WORDS: lichens, Cladonia, section Cocciferae, taxonomy, distribution.

\section{INTRODUCTION}

Cladonia diversa Asperges is a representative of the section Cocciferae (Delise) A. Evans. The section is wellknown for its numerous red-fruited Cladonia species. Most of them contain rhodocladonic acid in the hymenium which gives characteristic tint of the discs of apothecia. The group comprises about 65 species throughout the world (Huovinen et al. 1989) from which 17 were reported from Poland till now (Fałtynowicz 2003; see also Kowalewska and Kukwa 2004; Kukwa 2005; Osyczka 2006; Osyczka et al. 2006). Members of this section develop various types of secondary thallus - the podetia can be scyphose or blunt, covered with farinose to granular soredia, microsquamules, coricated granules and/or more or less areolate cortex. The determination of particular taxa is relatively simple when they additionally have diverse chemistry. Morphologically similar species which contain the same lichen substances are often most difficult to distinguish. Great morphological variability within the section still provides problems with delimitation of some taxa.

Cladonia diversa was distinguished from $C$. coccifera (L.) Willd. and $C$. pleurota (Flörke) Schaer. by Asperges (1983, 1985). All three taxa contain usnic acid and zeorin as main secondary lichen substances and therefore a chemical distinction is not possible. In general, Cladonia diversa differs from the latter two species by usually more narrow scyphi, slender podetia and densely microsquamulose-granulose surface of podetia. It is often fairly distinct, however, great morphological variability of the species may induce difficulties in its delimitation (especially from
C. coccifera). For this reason the taxon was often discussed together with $C$. coccifera or included as its synonym (e.g. Ahti and Stenroos 1986; Huovinen et al. 1989; Wirth 1995). However, the most recent papers consider $C$. diver$s a$ as a separate species (e.g. Coppins 2002; Söchting and Alstrup 2002; Santesson et al. 2004)

During revision of a cup-shaped Cladonia from the section Cocciferae in Poland some specimens were found to refer to $C$. diversa. The paper recognizes its distribution in Poland as well as provides discussion on its morphology, chemistry and ecology.

\section{MATERIAL AND METHODS}

The object of this revision were three scyphose Cladonia species from the section Cocciferae containing usnic acid and zeorin as major secondary lichen compounds: $C$. coccifera, C. pleurota and C. deformis (L.) Hoffm. Altogether 1121 specimens were examined. The material studied originated from the following Polish herbaria: BDPA, GPN, KRA, KRAM, KRAP, KTC, LBL, POZ, UGDA, WA, WRSL, Hb. Kolanko. As reference material the type collections of $C$. diversa were examined (BR - holotype, BM - isotype).

The morphology was examined using standard microscopic techniques. Chemical analyses were performed by TLC (in solvents A and C) according to the standardized methods (White and James 1985; Orange et al. 2001).

Metter-Toledo SevenEasy pH meter was employed for substratum $\mathrm{pH}$ determination. The study was made by su- 
spending substrate matter in pure water. The $\mathrm{pH}$ analysis was done for lichen specimens with sufficient amount of substrate material (min. $\sim 1.1 \mathrm{~g}$ ).

All ascertained localities of the species are listed and mapped according to the ATPOL gird square system (Zając 1978; modified by Cieśliński and Fałtynowicz 1993). The physiographical division of Poland used in the paper are based on Kondracki (2001). The following abbreviations in localities citation are used: NP - National Park; NR - nature reserve; LP - landscape park; fs - forest section; fd - forest division; vill. - village.

\section{RESULTS AND DISCUSSION}

Cladonia diversa was an overlooked lichen in Poland in the past, however, as a result of this study it was recognized as relatively frequent in the area. Below, the species is characterized and discussed in details.

Cladonia diversa Asperges (Fig. 1A-D)

De Cladonia's uit de sectie Cocciferae in België (morfologie, chemie, ecologie, sociologie, erspreiding en systematick) 2. Ph.D. Thesis (Wilrijk): 358 (1983).

Belgium, Kempisch district, Kalmthout, Van Ganzenven, 1974, M. Asperges 2498 (BR! - holotype, Figure 1A, see also Figure 1 in Asperges 1985; BM!, H, U - isotypes).

Morphology. The primary squamules are persistent and middle size, up to $0.5 \mathrm{~cm}$ long, protruding from the ground,
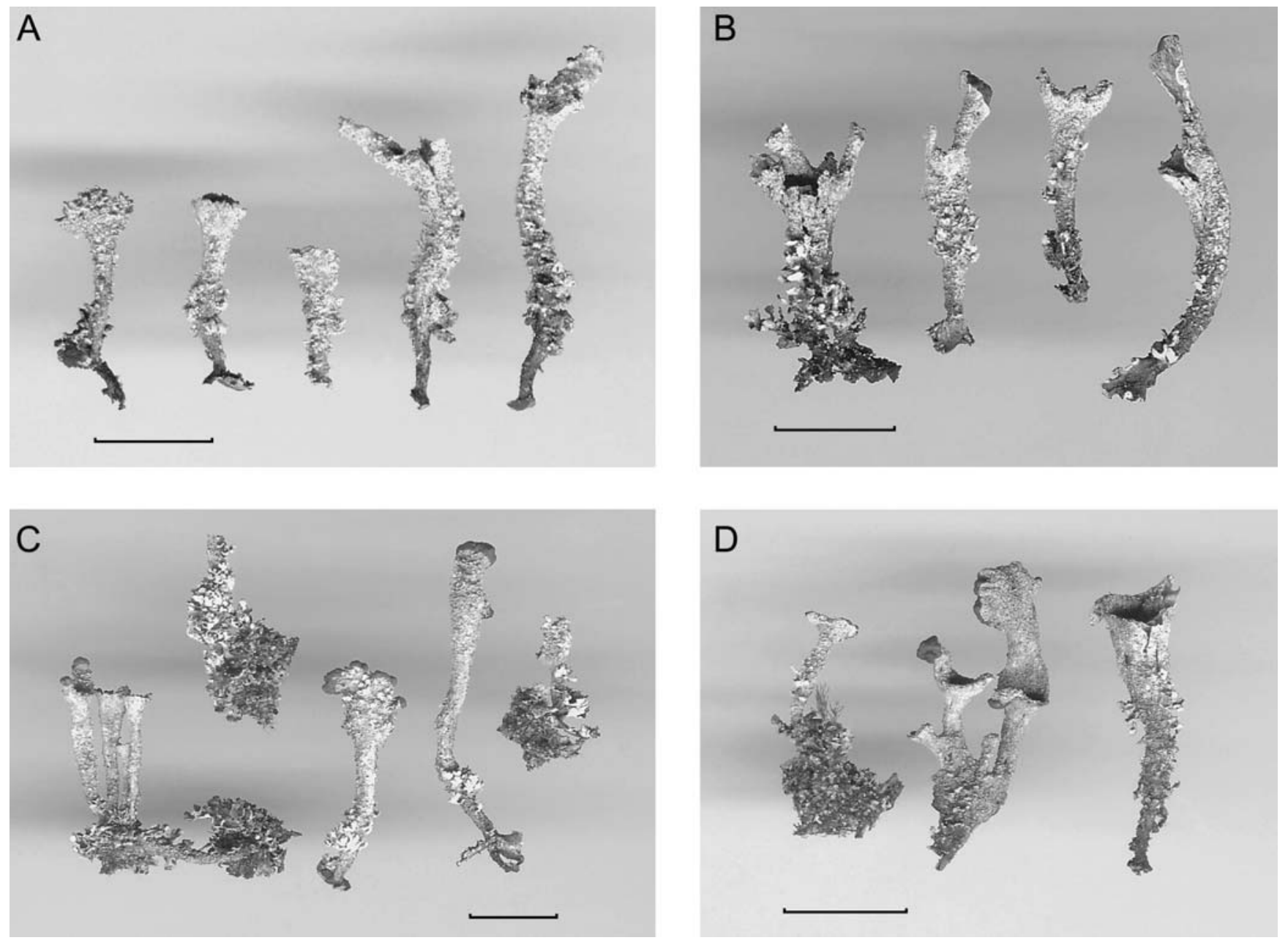

Fig. 1. Cladonia diversa Asperges: A - Asperges 2498, holotype (BR); B - W. Fałtynowicz, 29.07.1984 (UGDA-L-2553); C - M. Herbichowa and J. Herbich, 15.09.2004 (UGDA-L-11165); D - M. Kukwa, 24.06.1996 (UGDA-L-9730). Scale bars $=1 \mathrm{~cm}$.

sparsely divided into roundish lobes. The podetia are up to c. $3 \mathrm{~cm}$ tall, slender, unbranched or frequently with marginally proliferating scyphi. The scyphi are rather narrow, up to $0.5-0.7 \mathrm{~cm}$ wide, sometimes only a little wider than podetial stalk, usually gradually expanded. The surface of the podetia is esorediate and densely covered by corticated granules or/and microsquamules and scaly plates. Basal parts of podetia are often abundantly squamulose. More detailed description of the species is provided by Asperges (1985) and Stenroos (1989a, b).

Chemistry. The thallus of the species always contains usnic acid and zeorin as a major secondary substances. Apothecia (hymenia) contain rhodocladonic acid. Porphyrilic acid and bellidiflorin were reported by Asperges $(1983,1985)$ as the accessory substances sometimes produced by the species. Only in one specimen from Poland (UGDA-L-13159) porphyrilic acid was detected. This indicates that chemosyndrome of the species without this dibenzofurane is considerably frequent.

Ecology. Cladonia diversa is predominantly an epigeic lichen in Poland. Most of the specimens were collected from soil $(\sim 78 \%)$. The species inhabits also peat and decaying plant and mosses debris $(\sim 13 \%)$. On mosses and decaying wood $C$. diversa was found more rarely. It prefers primarily open habitats, like: pine forests, grasslands, dune areas, heathlands. Based on the $\mathrm{pH}$ analysis of substrate matter of selected specimens $(\mathrm{n}=28)$, it seems that $C$. diver$s a$ is a strictly acidophilous lichen. The $\mathrm{pH}$ range of 3.67-

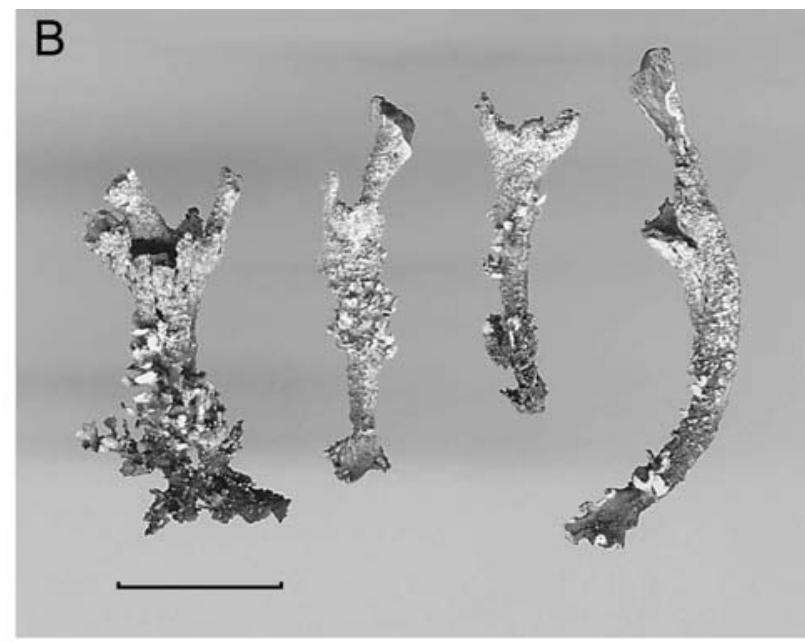




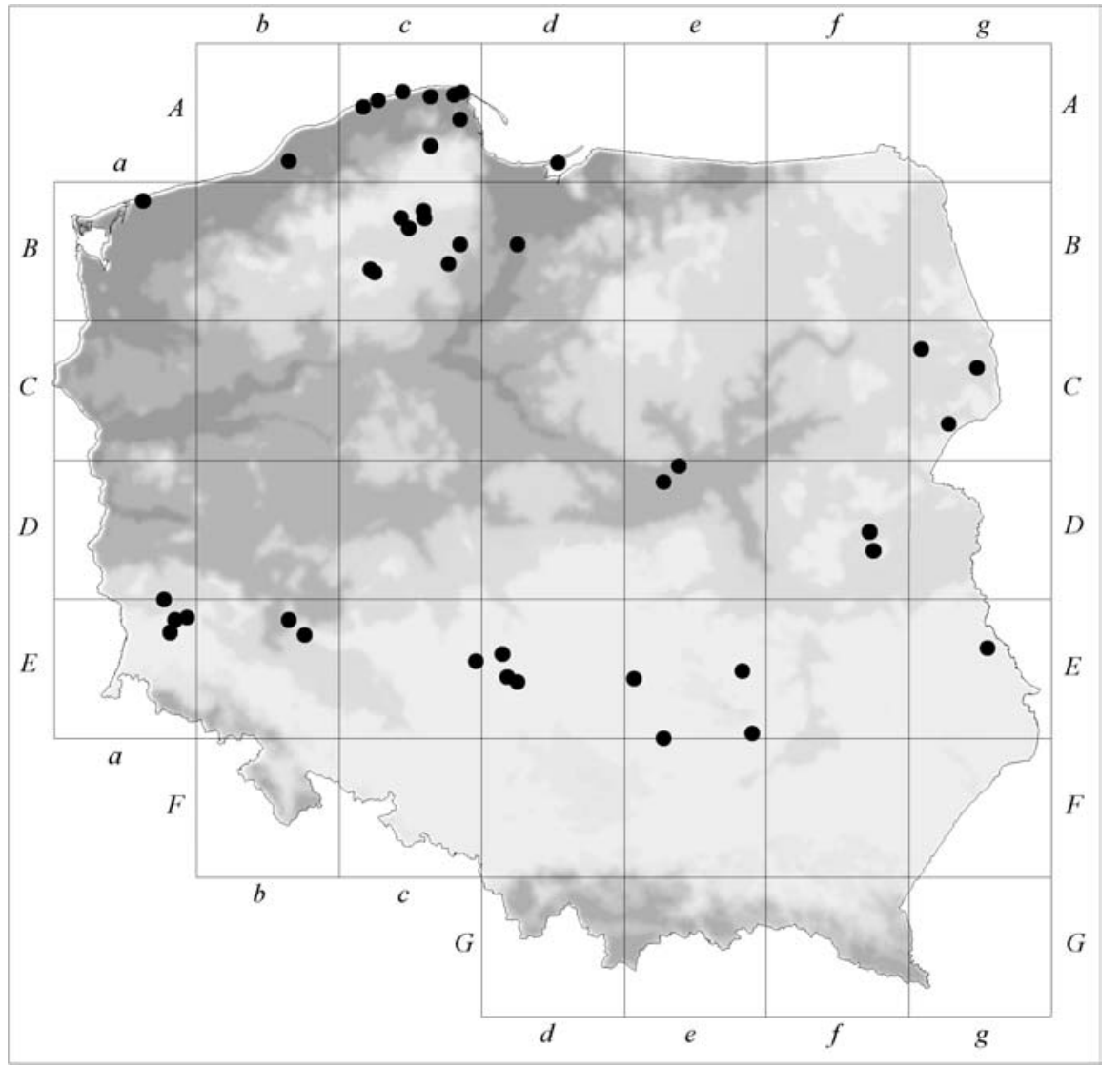

Fig. 2. Known distribution of Cladonia diversa Asperges in Poland given in ATPOL grid square system.
-4.46 was determined for substrates occupied by the species and such substrates can be qualified as strongly acid. For the one soil sample $\mathrm{pH}$ amounted 3.06 and it is defined as extremely acid kind of soil. The taxa from the section Cocciferae frequently demonstrate a tendency to occur on acid substrates (e.g. Wirth 1995).

Distribution in Poland. Currently known distribution of C. diversa in Poland is presented in Figure 2. Most of the species localities are situated in the northern part of Poland (the Pobrzeża Południowobałtyckie coastlands, the Pojezierza Południowobałtyckie lakelands, the Wysoczyzny Podlasko-Białoruskie plateau). The lichen seems to be particularly frequent near the Baltic coast. Several collecting sites are located across the central (the Niziny Sasko-Łużyckie lowlands, the Niziny Środkowopolskie lowlands, the Polesie region) and in the south-central part of Poland (the Wyżyna Śląsko-Krakowska upland, the Wyżyna Małopolska upland). The species was not recorded in the mountain areas of the country.

World distribution. The general distribution of $C$. diver$s a$ is not well recognized yet. In Europe the species has been reported inter alia from: Fennoscandia (Santesson 1993; Santesson et al. 2004), Iceland (Kristinsson 1999), Lithuanian (Motiejunaite 2002), United Kingdom (Coppins 2002), Denmark (Søchting and Alstrup 2002), Netherlands (Hasse and Daniëls 2006), Belgium (Asperges 1983, 1985), Germany (Scholz 2000), France (Asperges 1985; Stenroos 1989a), Iberian Paninsula (Burgaz and Ahti 1994; Llimona and Hladun 2001), and Italy (Tretiach 1992). Apart from Europe the species is known from China (Guo 1999), the U.S.A. (Lendemer 2006), and Macaronesia (Hafellner 1995; Etayo and Burgaz 1997).
Taxonomical remarks. Cladonia diversa belongs to the group of taxa from the section Cocciferae containing usnic acid and zeorin as a major lichen substances. It is morphologically often very similar to $C$. coccifera and also $C$. pleurota. There are, however, some distinguishing characters helpful for $C$. diversa determination: slender podetia, densely microsquamulose and/or granulose podetial surface, giving somewhat rugged appearance; usually narrow scyphi, and rather frequent lateral or marginal proliferations. Cladonia coccifera is squat, frequently forms wide scyphi (up to 1.5 diam.), has areolate and scaly cortical plates which are rather distracted. A distinction of Cladonia diversa from $C$. pleurota is easier because the latter has at least partly granulose sorediate surface of the podetia. Diagnostic characters separating these three species are also juxtaposed in the papers by Asperges (1985) and Stenroos (1989b).

Nomenclatural notes. The nomenclature of $C$. diversa Asperges is not clear. The species name is regarded to be effectively published under the Art. 29.1 of the Code (see Index Fungorum). However, according to the other recent sources (Diederich et al. 2009) the name requires validation based on the Art. 30 of Vienna Code. This important issue needs further consideration.

Specimens examined: [Ab-86] - c. $2 \mathrm{~km} \mathrm{~S}$ of Porzecze vill., on humous rock, 04.08.2004, leg. M. Kukwa 3421 (UGDA-L-10984); [Ac-34] - E part of Mierzeja Sarbska sand-bar, fs no. 14, on soil, 18.10.1985, leg. J. Miądlikowska (UGDA-L-3695); [Ac-36] - Powiat Morski district, Białogóra vill., on soil, 19.08.1953, leg. Z. Tobolewski (POZG); Mierzeja Łebska sand-bar, Białogóra fd, fs no. 
27m, c. $1 \mathrm{~km}$ NW of Białogóra vill., near Babnica NR, on soil, 31.07.2003, leg. R. Markowski (UGDA-L-9124); Białogóra fd, fs no. 10i, 15.09.2004, on soil, leg. M. Herbichowa and J. Herbich (UGDA-L-11165); [Ac-37] - Bielawskie Błoto, c. $2,5 \mathrm{~km}$ E of Sławoszynko vill., 08.10.1981, on decaying plant debris and mosses, leg. W. Fałtynowicz (UGDA-L-1180); [Ac-38] - Bielawskie Błoto, c. $2.5 \mathrm{~km} \mathrm{~W}$ of Mieroszyn vill., heathland, on decaying plant debris and mosses, 20.07.1981, leg. W. Fałtynowicz (UGDA-L-1188); Bielawskie Błoto, heathland, on soil, 24.07.1981, leg. W. Fałtynowicz (UGDA-L-1397); Bielawa NR, S of Moroszka Bielawskiego Błota NR, heathland with young pines and birches, on decaying peat, 17.06.2006, leg. M. Kukwa 5214 (UGDA-L-13004); [Ac-42] - Słowiński Park Narodowy NP, c. 2 km W of Wydma Łącka dune, on sandy soil, 15.08.1996, leg. M. Kukwa (UGDA-L-9790); Słowiński Park Narodowy NP, fs no. $60 \mathrm{~g}$, on decaying peat, no date, leg. J. Duriasz (UGDA-L-13159); [Ac-44] - Mierzeja Sarbska sand-bar near Łeba town, on sandy soil, 19.10.1985, leg. J. Miądlikowska (UGDA-L-3609); [Ac-51] - Słowiński Park Narodowy NP, c. $2 \mathrm{~km} \mathrm{~N}$ of Smołdziński Las vill., on soil, 24.06.1996, leg. M. Kukwa (UGDA-L-9730); [Ac-58] Wejherewo district, Biała Góra vill., on sandy soil, 29.09.1953, leg. Z. Tobolewski (LBL-61); Wejherowo district, Biała Góra vill., on soil, 29.08.1957, leg. K. Glanc (KRAM-L-39576); [Ad-85] - Przebrno vill., fs no. 75, on soil, 08.08.1982, leg. E. Budzbon (UGDA-L-1989); [Ba-16] - Pobierowo vill., on humous soil, 28.07.1996, leg. E. Kozioł (WRSL-98352); [Bc-24] - Bory Tucholskie forests, Popówka fd, fs no. 318n, on soil, 02.03.1975, leg. W. Fałtynowicz (UGDA-L-695); [Bc-25] - Wdzydzki Park Krajobrazowy LP, c. $0.5 \mathrm{~km} \mathrm{~W}$ of Schodno vill., on soil, 16.06.2003, leg. M. Kukwa 1840 (UGDA-L-10644); Wąglikowice vill., $500 \mathrm{~m}$ E of Kramsko Duże lake, on decaying wood, 14.11.1976, leg. W. Fałtynowicz (UGDA-L-916); [Bc-34] - Przymuszewo fd, between Lubnia and Wiele villages, fs no. 327/328, Bór Chrobotkowy im. Prof. Z. Tobolewskiego NR, on soil, 19.05.1999, leg. U. Bielczyk (KRAM-L-44758); Przymuszewo fd, fs no. 324iS, on soil, 05.04.1978, leg. W. Fałtynowicz (UGDA-L-407); [Bc-40] - NW of Człuchów vill., c. 2 km E of PKP Bielsko railway-station, heathland, on soil, 12.07.1987, leg. W. Fałtynowicz (UGDA-L-3126); [Bc-48] - Pojezierze Starogardzkie lakeland, between Ocypel vill. and Ocyplek lake, on soil, 29.07.1984, leg. W. Fałtynowicz (UGDA-L-2553); [Bc-57] - Rosochatka vill., $1 \mathrm{~km} \mathrm{~N}$ of Czersk town, heathland, on sandy soil, 30.09.1988, leg. W. Fałtynowicz (UGDA-L-4028); [Bc-62] - c. $20 \mathrm{~km} \mathrm{~N}$ of Człuchów town, near Nowa Wieś vill., $1 \mathrm{~km}$ of $\mathrm{S}$ bank of Krasne lake, on soil, leg. W. Fałtynowicz (UGDA-L-4300); [Bd-42] - Biały Dwór fd, fs no. 235, Ryjewo commune, on soil among mosses, 24.09.1996, leg. M. Kukwa (UGDA-L-9857); [Cg-34] - 0.5 km NW of Tanica Górna vill., on soil, 15.08.1992, leg. S. Cieśliński (KTC-1172); [Cg-10] c. $2 \mathrm{~km}$ E of Skroblanka vill., on soil, 13.05.1987, leg. S. Cieśliński and Z. Tobolewski (KTC-180); [Cg-72] - SW of Puszcza Białowieska forest, near Jelonka vill., on sandy soil, 1980, leg. S. Cieśliński (KTC); 2 km SW of Jelonka vill., on soil, 1980, leg. S. Cieśliński and Z. Tobolewski (KTC); [De-03] - Kampinoski Park Narodowy NP, Rybitwa vill., on soil, 18.09.1962, leg. J. Zielińska (WA); [De-12] - Kampinoski Park Narodowy NP, near Bieliny vill., on sandy soil, 12.07.1961, leg. J. Zielińska (WA); [Df-47] - Strzakły vill., on sandy soil, 1974, leg. A. Hawryluk (LBL); [Df-67] - Biała vill. near Radzyń town, on soil among mosses, 1974, leg. A. Hawryluk (LBL); [Ea-07] near Świętoszów vill., on soil, 19.08.1997, leg. E. Kozioł (WRSL-98348); [Ea-18] - Ławszów vill., Osiecznica commune, on soil among mosses, 16.08.1997, leg. E. Kozioł (WRSL-98346); Kliczków vill., heathland, on soil, 18.08.1997, leg. E. Kozioł (WRSL-98343); SE of Ławszów vill., heathland, on soil, 28.08.1998, leg. E. Kozioł (WRSL-98929); [Ea-19] - Trzebień vill., on dead mosses, 28.07.1992, leg. E. Kozioł (WRSL-98341); [Ea-28] - Tomisław vill., on humous soil, 04.09.1992, leg. E. Kozioł (WRSL-98342); [Eb-16] - Stary Wołów vill., on humous soil, 29.06.1996, leg. E. Kozioł (WRSL-98345); [Eb-27] Jodłowice vill. near Brzeg Dolny town, on humous soil, 17.07.1989, leg. E. Kozioł (WRSL-98340); [Ec-49] - Motyl vill. near Ożarów town, on soil, 21.06.1964, leg. J. Nowak (KRAM-L-12750); [Ed-41] - between Kamion and Krzeczów villages, on bank of Warta river, on soil, 23.06.1964, leg. J. Nowak (KRAM-L-12710); [Ed-51] Wapiennik vill. near Parzymiechy vill., on sandy soil, 18.06.1964, leg. J. Nowak (KRAM-L-42633); [Ed-52] Zawady vill. near Rogów vill., on sandy soil, 03.06.1964, leg. J. Nowak (KRAM-L-12478); Zawady vill., on soil, 03.06.1964, leg. J. Nowak (KRAM-L-13404); [Ee-50] between Pilczyca and Czamiętniki villages, dune area, 21.08.1975, leg. S. Cieśliński (KTC-290); [Ee-58] - Lubienia vill., on soil, 13.07.1973, leg. S. Cieśliński (KTC-7); [Ee-92] - Pogórze Szydłowskie foothills, S of Raków town, on soil, 1982, leg. S. Cieśliński (KTC); [Ee-99] - 5 $\mathrm{km} \mathrm{W}$ of Bogoria vill., Malkowice fd, fs no. 34, on sandy soil, 13.07.1986, leg. M. Chyb (KTC); [Eg-35] - Wólka vill. near bank of Bug river, on sandy soil, 31.08.1991, leg. S. Cieśliński (KTC-1129).

\section{ACKNOWLEDGEMENTS}

I am grateful to Teuvo Ahti (Helsinki) for valuable comments on the species and Lucyna Śliwa (Kraków) for very constructive discussion. I would like to thank Jacek Madeja (Kraków) for assistance with the $\mathrm{pH}$ determination of substrate materials. I would also like to thank the Curators of Polish and foreign herbaria sending me the material for the study. I am indebted to an anonymous reviewer for helpful remarks and corrections of the manuscript.

\section{LITERATURE CITED}

AHTI T., STENROOS S. 1986. A revision of Cladonia sect. Cocciferae in the Venezuelan Andes. Ann. Bot. Fenn. 23: 229-238 .

ASPERGES M. 1983. De Cladonia's uit de sectie Cocciferae in België (morfologie, chemie, ecologie, sociologie, erspreiding en systematick) 2. Ph.D. Thesis. University Antwerpen, Wilrijk, pp. 523.

ASPERGES M. 1985. Cladonia diversa Asperges en Europe occidentale. Dumortiera 32: 24-31.

Burgaz A.R., Ahti T. 1994. Contribution to the study of the genera Cladina and Cladonia in Spain. II. Nova Hedwigia 59 (3-4): 399-440.

CIEŚLIŃSKI S., FAŁTYNOWICZ W. 1993. Note from editors. In: Atlas of the geographical distribution of lichen in Poland. 
Cieśliński S., Fałtynowicz W. (eds). W. Szafer Institute of Botany, Polish Academy of Sciences, Kraków 1: 7-8.

COPPINS B.J. 2002. Checklist of lichens of Great Britain and Ireland. British Lichen Society, Huddersfield, pp. 95.

DIEDERICH P., ERTZ D., STAPPER N., SÉRUSIAUX E., VAN DEN BROECK D., VAN DEN BOOM P., RIES C. 2009. Lichens of Belgium, Luxembourg and northern France. http://www.lichenology.info, date of exploration: 06.05.2009.

ETAYO J., BURGAZ A.R. 1997. Contribution to the lichen-forming fungi from the Canary Islands III. The genus Cladonia. Ann. Naturhist. Mus. Wien 99B: 721-725.

FAŁTYNOWICZ W. 2003. The lichens, lichenicolous and allied fungi of Poland. An annotated checklist. Biodiversity of Poland 6. W. Szafer Institute of Botany, Polish Academy of Sciences, Kraków, pp. 435.

GUO S.Y. 1999. Fungal flora of tropical Guangxi, China: the lichen family Cladoniaceae. Mycotaxon 72: 339-347.

HAFELLNER J. 1995. A new checklist of lichens and lichenicolous fungi of insular Laurimacaronesia including a lichenological bibliography for the area. Fritschiana 5: 1-132.

HASSE T., DANIËLS F.J.A. 2006. Species responses to experimentally induced habitat changes in a Corynephorus grassland. J. Veg. Sci. 17: 135-146.

HUOVINEN K., AHTI T., STENROOS S. 1989. The composition and contents of aromatic lichen substances in Cladonia section Cocciferae. Ann. Bot. Fenn. 26: 133-148.

INDEX FUNGORUM. Available at http://www.indexfungorum.org, date of exploration: 06.05.2009.

KOWALEWSKA A., KUKWA M. 2004. Cladonia metacorallifera (lichenized Ascomycota, Cladoniaceae) new to Poland and additional record from Slovakia. Biologia (Bratislava) 59 (4): 433-434

KONDRACKI J. 2001. Geografia regionalna Polski. PWN, Warszawa, pp. 441.

KRISTINSSON H. 1999. The 12th meeting of the Nordic Lichen Society in Eidar, Iceland 1997. Graphis Scripta 11(1): 13-21.

KUKWA M. 2005. The lichen species Cladonia incrassata (Lecanorales, Ascomycota Lichenisati) in Poland, and notes on $C$. anitae. Pol. Bot. J. 50(1): 69-73.

LENDEMER J.C. 2006. Contributions to the lichen flora of New Jersey: a preliminary checklist of the lichens of Wharton State Forest. Opuscula Philolichenum 3: 21-40.
LLIMONA X., HLADUN N.L. 2001. Checklist of the Lichens and Lichenicolous Fungi of the Iberian Peninsula and Balearic Islands. Bocconea 14: 5-581.

MOTIEJUNAITE J. 2002. Additions to the Lithuanian flora of foliose and fruticose lichens Botanica Lithuanica 8(1): 69-76.

ORAGNE A., JAMES P.W., WHITE F.J. 2001. Microchemical methods for the identification of lichens. British Lichen Society, London, pp. 101.

OSYCZKA P. 2006. Cladonia borealis (Cladoniaceae, lichenized Ascomycota) in the Polish Carpathians. Pol. Bot. J. 51 (2): 230-232.

OSYCZKA P., WĘGRZYN M., FLAKUS A. 2006. Two species of the genus Cladonia (Cladoniaceae, lichenized ascomycota) new to the Polish Tatra Mts. Pol. Bot. J. 51(2): 233-235.

SANTESSON R. 1993. The Lichens and Lichenicolous Fungi of Sweden and Norway. SBT-förlaget, Lund, pp. 240.

SANTESSON R., MOBERG R., NORDIN A., TØNSBERG T., VITIKAINEN O. 2004. Lichen-forming and Lichenicolous Fungi of Fennoscandia. Museum of Evolution, Uppsala University, Uppsala, Sweden, pp. 359.

SCHOLZ P. 2000. Katalog der Flechten und flechtenbewohnenden Pilze Deutschlands. Schriftenreihe Vegetationsk. 31: 1$-298$.

SØCHTING U., ALSTRUP V. 2002. Danish Lichen Checklist. Botanical Institute, University of Copenhagen, Copenhagen, pp. 43.

STENROOS S. 1989a. Taxonomy of the Cladonia coccifera group. 1. Ann. Bot. Fenn. 26: 157-168.

STENROOS S. 1989b. Taxonomy of the Cladonia coccifera group. 2. Ann. Bot. Fenn. 26: 307-317.

TRETIACH M. 1992. Lichenological studies in NE-Italy. V. New records from Friuli-Venezia Giulia. Stud. Geobot. 12: 3-60.

WHITE F.J., JAMES P.W. 1985. A new guide to microchemical techniques for the I identification of lichen substances. Brit. Lich. Soc. Bull. (Suppl.) 57: 1-41.

WIRTH V. 1995. Die Flechten Baden-Württembergs. Teil 1. Verlag E. Ulmer, Stuttgart, pp. 527.

ZAJĄC A. 1978. Atlas of distribution of vascular plants in Poland (ATPOL). Taxon 27: 481-484. 